\title{
The relationship between sirtuin 1 (SIRT1) expression and tumor size, Proliferating Cell Nuclear Antigen (PCNA) expression and histological grading in rat breast carcinoma induced by dimethylbenz $(\alpha)$ anthracene (DMBA)
}

\author{
Novrita Padauleng $^{1 *}$, Dewajani Purnomosari ${ }^{2}$, Sri Herwiyanti ${ }^{2}$, Harjadi ${ }^{3}$, Irianiwati ${ }^{3}$, Sitarina \\ Widyarini ${ }^{4}$ \\ ${ }^{1}$ Faculty of Medicine, University of Mataram, West Nusa Tenggara, ${ }^{2}$ Department of \\ Histology, ${ }^{2}$ Department of Anatomical Pathology, Faculty of Medicine, ${ }^{4}$ Department of \\ Anatomical Pathology, Faculty of Veterinary, Universitas Gadjah Mada, Yogyakarta
}

\section{ABSTRACT}

Controversy regarding the role of SIRT1 in pathology of cancers exists and is still under debate. SIRT1 could act as either a tumor supressor or tumor promotor. This study was conducted to evaluate the relationship between SIRT1 expression and tumor size, Proliferating Cell Nuclear Antigen (PCNA) expression and histological grading in rat breast carcinoma induced by dimethylbenz(á)anthracene (DMBA). Thirty female Sprague Dawley rats were randomly allocated into three groups with 10 rats in each group. Group 1 as negative control was just fed the standard food. Group 2 as vehicle control was fed the standard food and corn oil. Group 3 as induction group was fed the standard food and induced with DMBA at dose of $20 \mathrm{mg} / \mathrm{kg}$ body weight (BW) in corn oil twice a week for five weeks. All rats were palpated weekly to determine the appearance, size and location of tumors. Sixteen weeks after DMBA induction rats were sacrified and histological preparations of the breast carcinoma tissue were then processed for SIRT1 and PCNA expression examination as well as histological grading. The result showed that SIRT1 expression was significantly higher in breast carcinoma tissue compared to normal gland (26.12 vs $0.05 ; p=0.004)$. SIRT1-positive was observed mostly in poor histological grade carcinomas $(56.2 \%)$, and it was not observed in good histological grade carcinomas. However, there was no significantly difference between SIRT1 and histological grading $(p=0.097 ; r=$ 0.285). A significant correlation between SIRT1 expression and the tumor size $(p=0.009 ; r$ $=0.877$ ), as well as PCNA expression ( $p=0.000 ; r=0.790$ ) was observed. In conclusion, there is relationship between SIRT1 expression and tumor size as well as PCNA expression in rat breast carcinoma induced by DMBA.

\section{ABSTRAK}

Kontrovesi mengenai peran SIRT1 dalam patologi kanker muncul dan masih diperdebatkan. SIRT1 dapat berperan sebagai penekan atau pemacu pertumbuhan tumor. Penelitian ini dilakukan untuk mengkaji hubungan antara SIRT1 dengan ukuran tumor, ekspresi Proliferating Cell Nuclear Antigen (PCNA) dan derajat histologi pada kanker payudara tikus yang diinduksi oleh dimetilbenz $(\alpha)$ antrasen (DMBA). Tiga puluh tikus Sprague Dawley betina dibagi secara acak menjadi tiga kelompok dengan masing-masing kelompok 10 ekor. Kelompok 1 sebagai kontrol negatif hanya diberi

\footnotetext{
* corresponding author: novrita9888@yahoo.com
} 
pakan standar. Kelompok 2 sebagai kontrol pembawa diberi pakan standar dan pembawa. Kelompok 3 sebagai kelompok induksi diberi pakan standar dan diinduksi dengan DMBA dosis $20 \mathrm{mg} / \mathrm{kg}$ berat badan (BB) dalam minyak jagung dua kali seminggu selama lima minggu. Semua tikus dipalpitasi setiap minggu untuk terjadinya tumor, ukuran dan lokasinya. Enam belas minggu setelah induksi DMBA, tikus dikorbankan dan dibuta preparat histologi jaringan kanker payudaranya untuk pemeriksaan ekspresi SIRT1 dan PCNA maupun derajad histologinya. Hasil penelitian menunjukkan ekspresi SIRT1 lebih tinggi secara nyata pada jaringan kanker dibandingkan jaringan normal $(26,12$ vs 0,$05 ; p=0.004)$. SIRT 1 positif dijumpai di hampir semua jaringan histologi derajad buruk $(56,2 \%)$ and tidak dijumpai di jaringan histologi derajad baik. Namun demikian tidak terdapat hubungan bermakan antara ekspresi SIRT1 dengan dejarad histologi $(p=0,097 ; r$ $=0,285)$. Hubungan bermakna dijumpai antara ekspresi SIRT1 dengan ukuran tumor $(p=$ $0,009 ; r=0,877$ ) demikian juga dengan ekspresi PCNA ( $p=0,000 ; r=0,790)$. Dapat disimpulkan, ada hubungan antara ekspresi SIRT1 dengan ukuran tumor dan ekspresi PCNA pada kanker payudara tikus yang diinduksi dengan DMBA.

Keywords: SIRT1 expression - DMBA induced rat breast cancer - histological grading - tumor size - PCNA expression

\section{INTRODUCTION}

The silent information regulator (SIR) genes (sirtuin) are a class of proteins that possess either mono-ADP-ribosyltransferase, or deacylase activity. Sirtuin present from bacteria to mamals. In mammals the sirtuin family comprises seven pro-teins (SIRT1-SIRT7), which vary in tissue specificity, subcellular localization, enzymatic activity and targets. The sirtuin has emerged as important regulators of diverse physiological and pathological events, including life-span extension, neurodegeneration, age-related disorders, obesity, heart disease, inflammation, and cancer. ${ }^{1-4}$

Sirtuin, notably SIRT1, have been studied for their role in cancers in past decade. However, controversy regarding relationship between sirtuin and cancers exists and is still under debate since it could act as either a tumor supressor or tumor promotor. ${ }^{2,5}$ On one hand, SIRT1 helps protect DNA from damage and oxidatif stress, maintains genomic stability, and limits activity in tumor cell growth. All of which suggest that SIRT1 would protect organism against cancer. On the other hand, SIRT1 promots cell survival under stress conditions that could directly involved in tumorigenesis.
In addition, SIRT1 suppresses the function of several tumor suppressors including p53, p73 and HIC1 that promots in tumor development and progression. ${ }^{2,5-7}$

Proliferating Cell Nuclear Antigen (PCNA) is proven to be a potential prognostic marker in breast cancer. Increased PCNA expression is associated with the increased of traditional prognostic factors value histological grading and tumor size ${ }^{8,9}$ In order to evaluate the role of SIRT1 in breast cancer and to find an alternative potential prognostic marker, this study was conducted to evaluate the association between SIRT1 expression and histological grading, tumor size, and PCNA expression in Sprague Dawley rat breast carcinoma induced by dimethylbenz $(\alpha)$ anthracene (DMBA).

\section{MATERIALS AND METHODS}

\section{Animals}

This was quasi experimental study with post test only control group design. Thirty Sprague Dawley female rats (23 days old) were obtained from LPPT (Laboratorium Pengujian dan Penelitian Terpadu/Integrated Research and Testing Laboratory), Uiversitas Gadjah Mada, Yogyakarta. Rats were haused five in each cage 
Padauleng et al., The relationship between sirtuin 1 (SIRT1) expression and tumor size, Proliferating Cell Nuclear Antigen (PCNA) expression and histological grading in rat breast carcinoma induced by dimethylbenz(a)anthracene (DMBA)

in room temperature on a 12-hour cycles of dark and light. Rats were fed a standard food laboratory and provided an access to water $a d$ libitum.

\section{Breast carcinoma induction}

After an acclimatization period of one week at 30 days of age, rats were randomly allocated to three groups with 10 rats in each group. Group 1 as negative control was just fed the standard food. Group 2 as vehicle control was fed the standard food and corn oil. Group 3 as induction group was fed the standard food and induced with DMBA at dose of $20 \mathrm{mg} / \mathrm{kg}$ body weight (BW) in corn oil twice a week for five weeks as conducted by Meiyanto et al..$^{10}$ All rats were kept under previously described environmental conditions and palpated weekly using slide caliper to determine the appearance, size and location of tumors. Sixteen weeks after DMBA induction rats were sacrified. The rats were anesthetized using diethyl ether. Dissection was performed on thoracic and abdominal mammary glands and mammary tumors were removed. Histological preparations were then processed for SIRT1 and PCNA expression examination as well as histological grading. This study has approved by Medical and Health Research Ethics Committee, Faculty of Medicine, Universitas Gadjah Mada, Yogyakarta.

\section{Immunohistochemistry Staining}

Immunohistochemistry (IHC) for SIRT1 and PCNA was performed using Trekki Universal Link Detection System, in 4- $\mu \mathrm{m}$ sections of formalin-fixed, paraffin-embedded breast tissues, as well as breast carcinoma tissues. Endogenous peroxidase was quenched by incubation of $0.3 \%$ hydrogen peroxide for 15 minutes at room temperature. The sections were immersed in citrate buffer solution for 25 minutes at high temperature to retrieve the antigen, followed by incubation of primary antibody, SIRT1 monoclonal antibody 1:400 (Abcam110304) for overnight, and PCNA polyclonal antibody 1:1000 (Bioscience 8120365 ) for 10 minutes. A cell was considered as SIRT1 positive if a brown color of the cell was identified, whereas tissue was considered as SIRT1-positive if more than $30 \%$ of the cells showed SIRT1 positive. ${ }^{11}$

\section{Histological Grading}

Histological grading was performed in Hematoxylin Eosin stained sections. According to the Elston-Ellis modified Bloom Richardson classification system, the grade for each section was derived from an assessment of tubule formation, nuclear pleomorphism, and mitotic counts, with each feature being scored 1 to 3 points. ${ }^{12}$ The scores were added to obtain the histological grade as follows: 3-5 = Grade 1 (Good); 6-7 = Grade 2 (Moderate); and 8-9= Grade 3 (Poor). Mitotic feature was visualized using the immunohistochemistry method for PCNA.

\section{Statistical Analysis}

SIRT1 expressions between the 3 experimental groups were compared using statistical analysis of one-way ANOVA. The differences in SIRT1 expression based on the histological appearance (normal or carcinoma) were analyzed by Independent t-test. The association between SIRT1 expression (cut-off point $30 \%$ ) and histological grading was analyzed by Spearman test, while Pearson correlation test was applied to analyze the association between SIRT1 expression and tumor size, as well as PCNA expression.

\section{RESULTS}

A total of 10 female rats were induced with DMBA in Group 3, six (60\%) of which appear 
nodules with microscopic features of breast carcinoma (TABLE 1 and FIGURE 1). The number of total nodules that emerged during 16 weeks of observations was 7 nodules. Nodules first appeared at week 4 after the first DMBA induction (1 rats). Last nodules appeared at week 10 after the first DMBA induction (1 rats). The mean latency time of nodules appearance was 6.4 weeks, whereas the nodule size varied from 60 to $18,790 \mathrm{~mm}^{3}$. Histological classification of the breast tissue using hematoxilin eosin staining showed normal breast tissue in Group 1 and 2, as well as ductal type of breast carcinoma in Group 3 (FIGURE $1)$. The six rats with nodules were then analyzed, while 4 rats with neither nodule nor microscopic features of breast carcinoma were excluded from the study. No nodules were observed in all rats of Group 1 and 2.

TABLE 1. Characteristics of Sprague Dawley rats breast carcinoma after induction with DMBA

\begin{tabular}{ccccc}
\hline \multirow{2}{*}{$\begin{array}{c}\text { Rat } \\
\text { number }\end{array}$} & \multicolumn{4}{c}{ Characteristics of the breast carcinoma } \\
\cline { 2 - 5 } & Total nodule & $\begin{array}{c}\text { Latency time } \\
(\text { Wecks })\end{array}$ & $\begin{array}{c}\text { Tumor size } \\
\left(\mathrm{mm}^{3}\right)\end{array}$ & Histology type \\
\hline 1 & 2 & 4 & 18,790 & Carcinoma \\
& 1 & 6 & 1,200 & Carcinoam \\
2 & 1 & 7 & 210 & Carcinoam \\
3 & 1 & 6 & 1,060 & Carcinoma \\
4 & 1 & 6 & 1,550 & Carcinoma \\
5 & 1 & 10 & 1,980 & Carcinoma \\
6 & 1 & 60 & Carcinoma \\
\hline
\end{tabular}

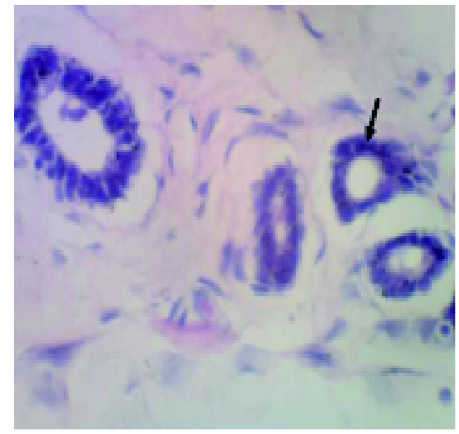

A

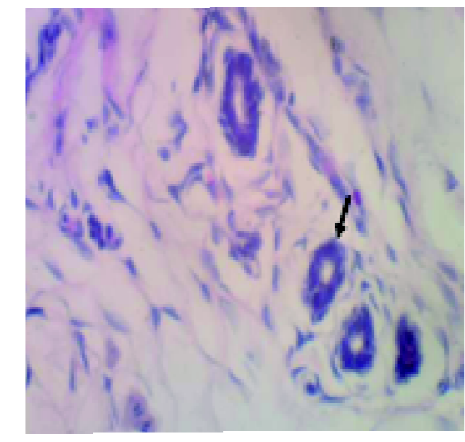

B

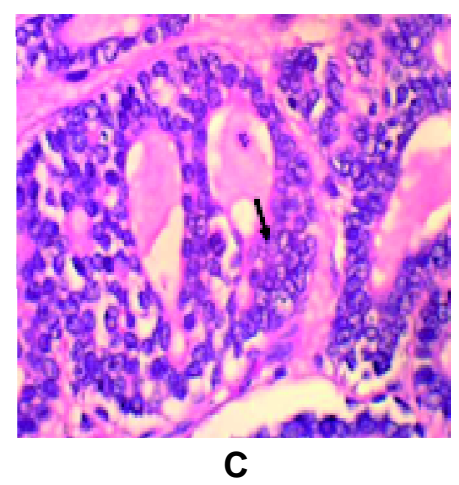

C

FIGURE 1. Histological appearance of the breast tissue of Sprague Dawley rats in the 3 experimental groups (HE, 400x). A. Normal gland of rats in Group 1; and B. Group 2. Single cuboids' cells lining the ducts (black arrow); C. Ductal carcinoma with the proliferation of pleomorphic cells in Group 3 
Padauleng et al., The relationship between sirtuin 1 (SIRT1) expression and tumor size, Proliferating Cell Nuclear Antigen (PCNA) expression and histological grading in rat breast carcinoma induced by dimethylbenz(a)anthracene (DMBA)

TABLE 2 showed the SIRT1 expression of the three groups, whereas FIGURE 2 showed the breast carsinoma tissue with SIRT1 expression negative and positive. Significantly difference in SIRT1 expression between the three groups was observed in this study ( $p=$ $0.000)$. The SITR1 expression in Group 3 $(26.13 \pm 1.55 \%)$ was significantly higher than those in Group $1(0.05 \pm 0.01 \%)$ and $2(0.06 \pm$ $0.01 \%)(\mathrm{p}=0.04)$. It was indicated that the SIRT1 expression in the breas carcinoma tissue was higher than those in breast normal tissue. Furthermore, Pearson analysis showed significant positive correlation between SIRT 1 expression and tumor size $(p=0.009 ; r=0.877)$.

TABLE 2.The SIRT1 expression and histological type on the three groups

\begin{tabular}{ccccccc}
\hline & \multicolumn{2}{c}{ Group 1 } & \multicolumn{2}{c}{ Group 2 } & \multicolumn{2}{c}{ Group 3 } \\
\cline { 2 - 6 } Rat & $\begin{array}{c}\text { SIRT1 } \\
\text { expression } \\
(\%)\end{array}$ & $\begin{array}{c}\text { Histology } \\
\text { type }\end{array}$ & $\begin{array}{c}\text { SIRT1 } \\
\text { expression } \\
(\%))\end{array}$ & $\begin{array}{c}\text { Histology } \\
\text { type }\end{array}$ & $\begin{array}{c}\text { SIRT1 } \\
\text { expression } \\
(\%)\end{array}$ & $\begin{array}{c}\text { Histology } \\
\text { type }\end{array}$ \\
\hline 1 & 0.00 & Normal & 0.00 & Normal & 36.19 & Carcinoma \\
2 & 0.00 & Normal & 0.03 & Normal & 24.93 & Carcinoma \\
3 & 0.16 & Normal & 0.05 & Normal & 25.75 & Carcinoma \\
4 & 0.10 & Normal & 0.19 & Normal & 27.90 & Carcinoma \\
5 & 0.00 & Normal & 0.08 & Normal & 32.71 & Carcinoma \\
6 & 0.02 & Normal & 0.00 & Normal & 9.27 & Carcinoma \\
\hline Mean \pm SEM & $0.05 \pm 0.01$ & \multicolumn{3}{c}{$0.06 \pm 0.01$} \\
\hline
\end{tabular}
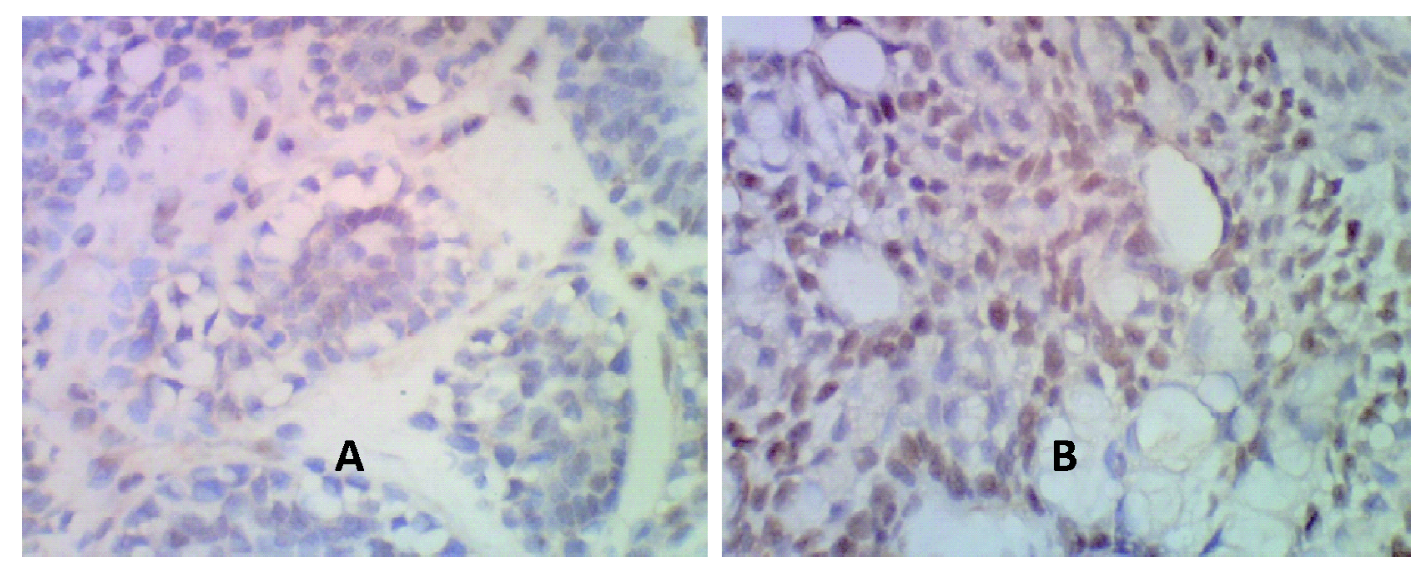

FIGURE 2. SIRT1 expression in the Sprague Dawley rats breast carcinoma tissue induced by DMBA (400x). A. SIRT1 negative tissue; B. SIRT1 positive tissue

FIGURE 3 showed the breast carcinoma tissue with PCNA negative and positive. Furthermore, Pearson analysis showed significant positive correlation between SIRT1 expression PCNA expression $(\mathrm{p}=0.000 ; \mathrm{r}=$ 0.790). 

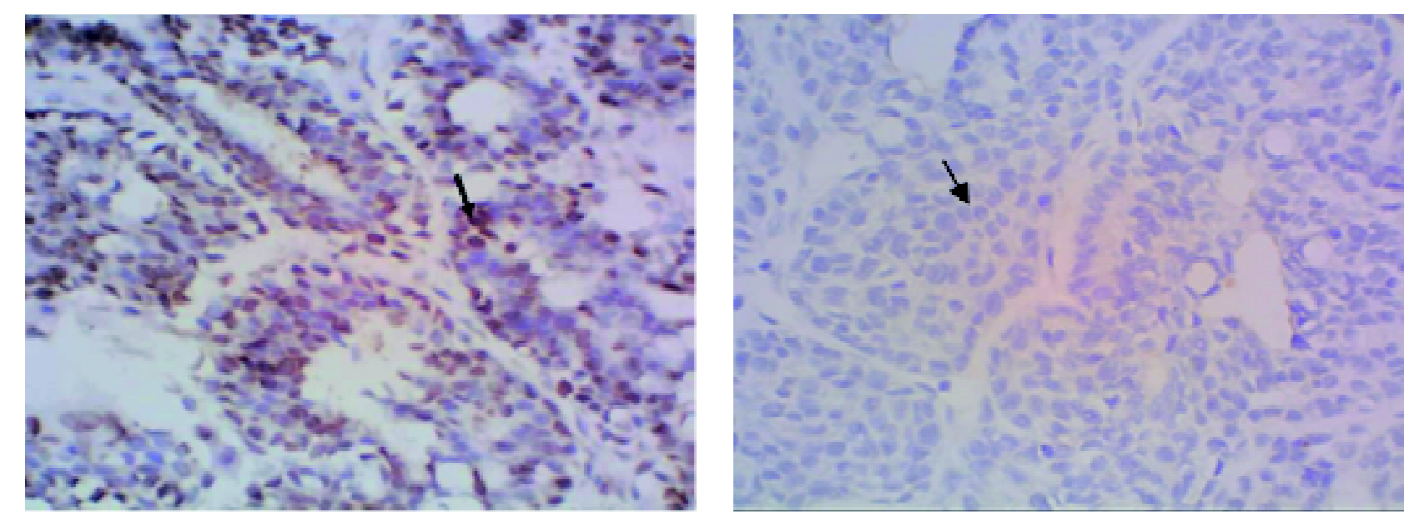

FIGURE 3. PCNA expression in Sprague Dawley the breast carcinoma induced by DMBA (400x). A. PCNA expression positive cells (black arrow). B. PCNA expression negative (black arrow)

Histological grading of the breast carcinoma tissue is presented in TABLE 4. SIRT1 expression postive was observed mostly in poor histological grade carcinoma. In contrast, it was not observed in good histological grade carcinoma. However, Pearson analysis showed no significantly correlation between SIRT1 expression and hitological grading in the breast carcinoma tissue $(\mathrm{p}=0.097 ; \mathrm{r}=0.285)$.

TABLE 3. The correlation between SIRT1 expression and histological grading in the Sprague Dawley rats breast carcinoma tissue induced by DMBA

\begin{tabular}{lcccccc}
\hline \multirow{2}{*}{ SIRT1 expression } & \multicolumn{3}{c}{ Histological grading } & Total & I & p \\
\cline { 2 - 5 } & 1 & 2 & 3 & & & \\
\hline Positive $(=30 \%)$ & $0(0 \%)$ & $7(43.7 \%)$ & $9(56.3 \%)$ & 16 & 0.285 & 0.097 \\
Negative $(<30 \%)$ & $2(10.5 \%)$ & $11(57.9 \%)$ & $6(31.6 \%)$ & 19 & & \\
\hline Tolal & 2 & 18 & 15 & 35 & \\
\hline
\end{tabular}

\section{DISCUSSION}

This study showed that SIRT1 expression in the breast carcinoma tissue of Sprague Dawley rats induced by DMBA was significantly higher than its expression in those normal tissue. This finding indicated that SIRT1 acts as tumor promotor that cause breast carcinoma progression of the rats. The role of SIRT1 as tumor promotor was supported by the increase tumor size as well as PCNA expression.

Previous studies on breast carcinoma, as well as other type of cancer, such as prostate and colon cancer, proved that SIRT1 expression was higher in cancer tissue compared to normal tissue. ${ }^{12-14}$ The mechanism by which SIRT1 stimulates the progression of breast carcinoma can be explained by its deacetylation activity on pro-apoptotic substrate target, such as p53, E2F1, Foxo, RB, and Ku70. ${ }^{15,21}$ SIRT1 is regulated at transcriptional, translational, and post-translational levels. A few proteins have been reported to modulate the expression and function of SIRT1 protein, such as E2F1, cMYC, HIC1, and Foxo 3a, at the level of 
Padauleng et al., The relationship between sirtuin 1 (SIRT1) expression and tumor size,

Proliferating Cell Nuclear Antigen (PCNA) expression and histological grading in rat breast carcinoma induced by dimethylbenz(a)anthracene (DMBA)

transcription $^{22,23}$ at the level of translation (HuR), ${ }^{24}$ and also DBC1 at the level of posttranslation..$^{25,26}$

The association between SIRT1 expression and histological grading showed that SIRT1positive was observed mostly in poor histological grade carcinomas and no SIRT1positive was found in good histological grade carcinoma. However, there was no significantly correlation between SIRT1 expression and histological grading in the breast carcinoma of rats induced by DMBA. The small sample size (35 slides from 6 rats), and case distribution $(2$ sections of grade $1 ; 18$ sections of grade 2 ; and 15 sections of grade 3) might be the cause of this insignificant result.

The increased of SIRT1 expression will also increased the SIRT1 deacetylation activity to several pro-apoptotic proteins, such as E2F1, $\mathrm{RB}, \mathrm{p} 53$, and Foxo. Those activities result in the progressivity of breast carcinoma, indicated by the decreased form of tubular structure (tubulus formation), which was caused by the growth of proliferating carcinoma cells, as well as the higher mitotic activity in histological grading analysis.

Present study also showed positive correlation between SIRT1 expression and tumor size, as well as PCNA expression. SIRT1 deacetylation activity to several pro-apoptotic proteins was assumed as the cause of proliferative signal hyperactivity, marked by the increased of tumor size, as well as PCNA expression, along with the increased of SIRT1 expression in this kind of animal experimental model.

\section{CONCLUSION}

In conclusion, there is relationship between SIRT1 expression and tumor size as well as PCNA expression in rat breast carcinoma induced by DMBA. However, this result should be confirmed by further study concerning SIRT1 deacetylation activity on target proteins as well as regulator proteins of SIRT1.

\section{ACKNOWLEDGEMENT}

The author would like to express gratitude to the HPEQ (Health Professional Education Quality) Project who had provided the fund in conducting this research.

\section{REFERENCES}

1. Kellin G. A review of the sirtuin system, a clinical implications, and the potential role of dietary activators like resveratrol. Part I. Alter Med Rev 2010; 15(3): 245-63.

2. Lin $Z$ and Fang D. The roles of SIRT1 in cancer. Genes \& Cancer 2013; 4(3-4): 97-104.

3. Houtkooper RH, Pirinen E, Auwerx J. Sirtuins as regulators of metabolism and healthspan. Nature Rev. Mol Cell Biol 2012; 13: 225-38.

4. Yamamoto H, Schoonjans K, Auwerx J. Sirtuin functions in health and disease. Mol Endocrinol 2007; 21(8): 1745-55.

5. Bosch- Presegué L and Vaquero A. The dual role of sirtuins in cancer 2011; Genes \& Cancers 2011; 2(6): 648-62.

6. Fan W, Luo J. SIRT1 regulates UV-induced DNA repair through deacetylating XPA. Mol Cell 2010;39:247-58.

7. Firestein R, Blander G, Michan S, Oberdoeffer P, Ogino S, Campbell J, et al. The SIRT1 deacetylase suppresses intestinal tumorigenesis and colon cancer growth. PLoS One 2008; 3(4):1-9.

8. Malkas LH, Herbert BS, Abdel-Aziz W, Dobroklecki LE, Liu Y, Agarwal B, et al. A cancerassociated PCNA expressed in breast cancer has implications as a potential biomarker. Proc Natl Acad Sci USA 2006; 103(51): 19472-77.

9. Schonborn, Minguillon C, Miihnert M, Ebelingt $\mathrm{K}$. PCNA as potential prognostic marker in breast cancer. Breast 1994; 3:97-102.

10. Meiyanto E, Tasminatun S, Susilowati S, Murwanti $\mathrm{R}$, Sugiyanto. Inhibition at the initiation phase of breast carcinogenesis in DMBA-induced rats by Gynura procumbens leaves extract (Lour), Merr. Majalah Farmasi Indonesia 2007; 18(4):169-75. 
11. Lee H, KimKR, Noh SJ, Park HS, Kwon KS, Park BH, Jung SH, Youn HJ, Lee BK, Chung MJ, Koh DH, Moon WS, Jang KY. Expression of DBC1 and SIRT1 is associated with poor prognosis for breast carcinoma. Hum Pathol 2011; 42(2):204-13.

12. Huffman DM, Grizzle WE, Bamman MM, Kim JS, Eltoum IA, Elgavish A, et al. SIRT1 is significantly increased in human and mouse prostate cancer. Cancer Res 2007; 67(14):66128.

13. Firestein R, Blander G, Michan S, Oberdoeffer P, Ogino S, Campbell J, et al. The SIRT1 deacetylase suppresses intestinal tumorigenesis and colon cancer growth. PLoS One 2008; 3(4):1-9.

14. Haigis MC, Sinclair DA. Mammalian sirtuins: biological insights and disease relevance. Annu Rev Pathol 2010; 5:253-95.

15. Luo J, Nikolaev AY, Imai S, Chen D, Su F, Shiloh A, et al. Negative control of p53 by Sir2 alpha promotes cell survival under stress. Cell 2001; 107(2):137-48.

16. Vaziri H, Dessain SK, Ng Eaton E, Imai SI, Frye RA, Pandita TK, et al. hSIR2 (SIRT1) functions as an NAD-dependent p53 deacetylase. Cell 2001; 107(2):149-59.

17. Wang C, Chen L, Hou X, Li Z, Kabra N, Ma Y, et al. Nemoto S, Finkel T, Gu W, Cress WD, Chen J. Interactions between E2F1 and SIRT1 regulate apoptotic response to DNA damage. Nat Cell Biol 2006; 8(9):1025-31

18. Zou Y, Tsai WB, Cheng CJ, Hsu C, Chung YM, Li $\mathrm{PC}$, et al. Forkhead box transcription factor FOXO3a suppresses estrogen-dependent breast cancer cell proliferation and tumorigenesis. Breast Cancer Res 2008; 10(1):21.

19. Motta MC, Divecha N, Lemieux M, Kamel C, Chen D, Gu W, et al. Mammalian SIRT1 represses forkhead transcription factors. Cell 2004; 166(4):551-63.

20. Wong S, Weber JD. Deacetylation of the retinoblastoma tumour suppressor protein by SIRT1. Biochem J 2007; 407(3):451-60.

21. Jeong J, Juhn K, Lee H, Kim SH, Min BH, Lee $\mathrm{KM}$, et al. SIRT1 promotes DNA repair activity and deacetylation of Ku70. Exp Mol Med 2007; 39(1):8-13.

22. Chen WY, Wang DH, Yen RC, Luo J, Gu W, Baylin SB. Tumor suppressor HIC1 directly regulates SIRT1 to modulate p53-dependent DNA-damage responses. Cell 2005; 123(3):437-48.

23. Nemoto S, Fergusson MM, Finkel T. Nutrient availability regulates SIRT1 through a forkheaddependent pathway. Science 2004; 306(5704): 2105-8.

24. Nemoto S, Fergusson MM, Finkel T. Nutrient availability regulates SIRT1 through a forkheaddependent pathway. Science 2004; 306(5704): 2105-8.

25. Abdelmohsen K, Pullmann R Jr, Lal A, Kim HH, Galban S, Yang X, Blethrow JD, Walker M, Shubert J, Gillespie DA, Furneaux H, Gorospe M. Phosporylation of HuR by Chk2 regulates SIRT1 expression. Mol Cell 2007; 25(4):543-57.

26. Kim JE, Chen J, Lou Z. DBC1 is a negative regulator of SIRT1. Nature 2008; 451(7178): 583-6. 